\title{
THE NORTH GREENLAND FOLD BELT BETWEEN CENTRAL JOHANNES V. JENSEN LAND AND EASTERN NANSEN LAND
}

\author{
A. K. Higgins, J. D. Friderichsen and N. J. Soper
}

The part of the North Greenland fold belt mapped in 1980 includes Johannes V. Jensen Land west of Polkorridoren, the group of large islands to the west, and the eastern margin of Nansen Land (Map 2). The rocks forming the fold belt are mainly Lower Palaeozoic turbiditic sediments, deposited in an E-W trending trough which is an extension of the Hazen trough of northern Ellesmere Island, Canada.

Observations on the stratigraphy, structure and metamorphism of the fold belt are given in this report. Brief descriptions of the E-W trending Harder Fjord fault zone, the Kap Cannon thrust zone, and important swarms of basic dykes are also included.

A geological map covering the parts of the North Greenland fold belt mapped in both 1979 and 1980 is found in the back of this report (Map 2), and includes all the place names mentioned in the text.

\section{Stratigraphy}

The four-fold subdivision of the rock sequence north of the Harder Fjord fault zone (Soper et al., 1980), based on earlier work (Dawes \& Soper, 1973, 1979), is used in this account. South of the fault zone a different, informal stratigraphy has been employed (Dawes \& Soper, 1979; Pedersen, 1980). Finds in 1979 of Lower Llandovery graptolites in the upper part of the sequence north of the fault zone provided a biostratigraphic link between the two stratigraphies (Surlyk et al., 1980; Hurst \& Surlyk, 1980). In 1980, two of the major lithostratigraphic divisions known north of the fault zone, were found also to the south underlying the previously lowest known unit. These and other observations have removed some of the uncertainties of previous correlations; a general correlation of the stratigraphies on the two sides of the Harder Fjord fault zone is shown in fig. 13. A revised, comprehensive stratigraphy for the Lower Palaeozoic trough sequence by J. M. Hurst, F. Surlyk, S. A. S. Pedersen and the writers, to be published in several parts, is in preparation.

\section{Unnamed quartzite group}

The lowest unit of the trough sequence so far known comprises quartzites and black phyllites, found in 1979 beneath the Paradisfjeld Group in easternmost Johannes V. Jensen Land, $10 \mathrm{~km}$ south-west of Kap Ole Chiewitz (Map 2). In 1980 the same rock units were found to cover more extensive areas on the south-east side of Frederick E. Hyde Fjord in continuation of the previously known outcrop area. The contact with the Paradisfjeld Group is strongly folded, but appears to have been conformable. Christie \& Ineson (1979) made 


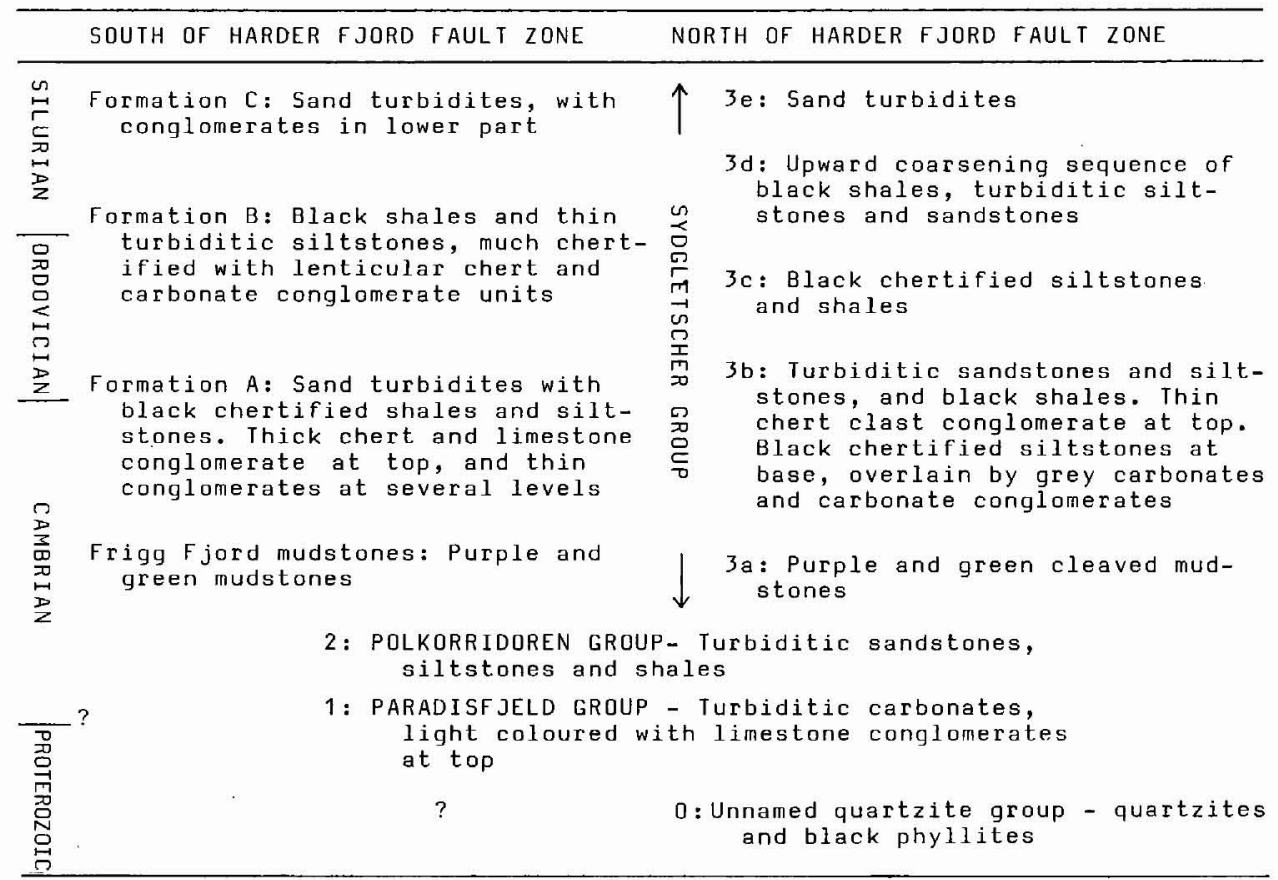

Fig. 13. General correlation of the stratigraphies north and south of the Harder Fjord fault zone.

brief observations on these rocks, which they presumed to be Precambrian - very probably a correct assessment of their age, though correlation with the Precambrian sequences of other areas is problematical. Within the main 1980 mapping area, the only representatives of this group were found in a small structural inlier making up two islands in Weyprecht Sund and the adjacent mainland (Map 2).

\section{Paradisfjeld Group}

The Paradisfjeld Group is widely exposed in northern and western parts of the 1980 mapping area, and is everywhere intensely folded which gives rise to complex outcrop patterns. The total thickness of the group is difficult to estimate, but must be at least $1000 \mathrm{~m}$.

Between Moa $\varnothing$ and eastern Nansen Land the succession shows a uniform development, on both sides of the Harder Fjord fault zone. Dark grey to black impure carbonates dominate. They are commonly poorly bedded with fragmental textures, and in places show oolitic bands. A few light-coloured carbonate units occur within these dark-coloured rocks, but are not sufficiently distinctive to permit subdivisions to be made. Only the uppermost $50-150 \mathrm{~m}$ of the Paradisfjeld Group forms a distinct mappable unit. This unit consists of a characteristic sequence of light-coloured, bedded carbonates (fig. 14); towards the top there are numerous beds of limestone conglomerates, which vary between $10 \mathrm{~cm}$ and $10 \mathrm{~m}$ in thickness and alternate with beds of calcareous shale or calcareous siltstone. The uppermost conglomerate bed is distinguishable by clastic quartz grains in the matrix. Up to $15 \mathrm{~m}$ of 


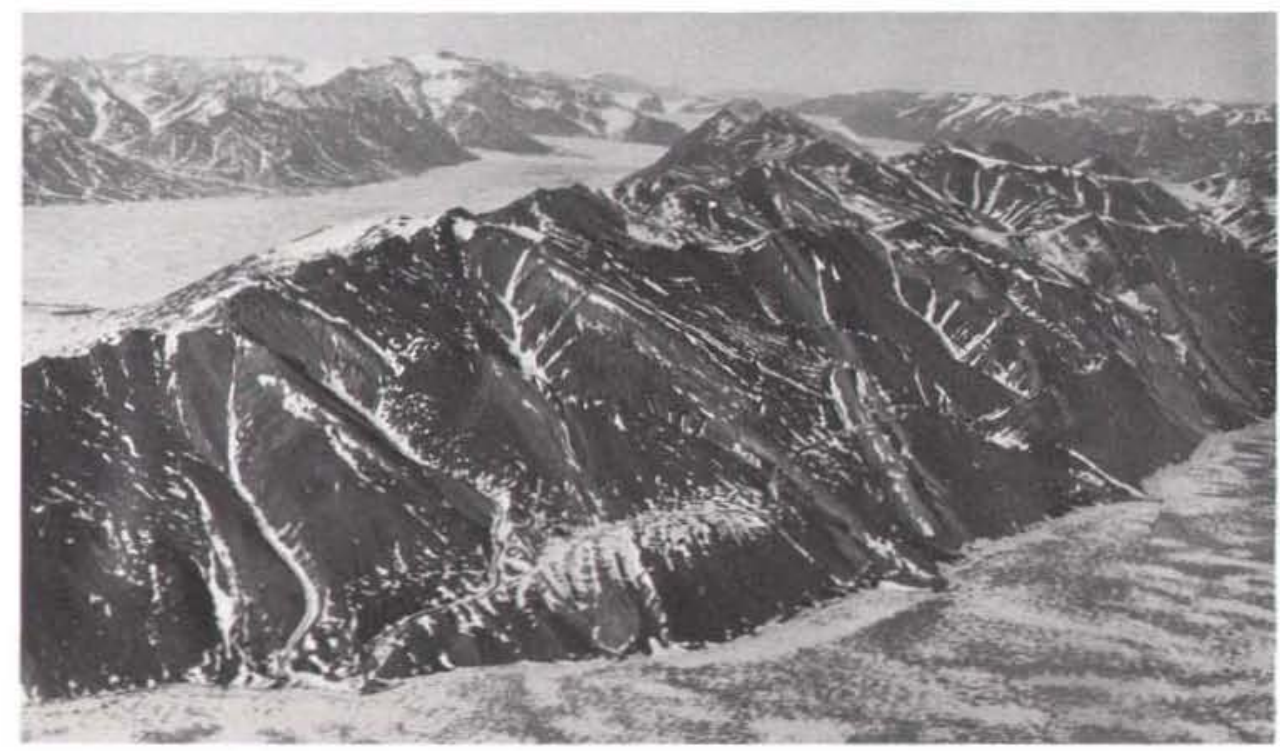

Fig. 14. Northerly overturned, tight folds on the west side of Hazen Land, viewed from the north-west. The ridge is about $750 \mathrm{~m}$ high. The light coloured band repeated by folding consists of light carbonates and limestone conglomerates at the top of the Paradisfjeld Group. It is overlain by dark turbiditic sandstones and siltstones of the Polkorridoren Group.

orange-weathering, calcareous siltstones form a transitional series into the overlying Polkorridoren Group.

In the northern parts of the area, between Weyprecht Sund in the west and Sands Fjord and Paradisfjeld in the east, the Paradisfjeld Group shows a different development. Calcareous phyllites form the lowest unit between A. Harmsworth Gletscher and Paradisfjeld, and are arranged in thin but continuous orange-weathering horizons; in Gertrud Rask Land to the north they occupy larger areas and are developed as calcareous mica schists. Dark grey limestones are common between A. Harmsworth Geltscher and Paradisfjeld, but virtually absent farther north; they form rather inhomogeneous, often easily weathered sequences. Pale grey to white, in places yellow-weathering limestone or marble form distinct marker bands in much of the area, overlain by well-banded, black limestone in some areas, and orange-weathering, calcareous phyllites in other areas. Conglomeratic limestone units are virtually absent.

Fossils from the upper levels of the group north-east of Midtkap on the north side of Frederick E. Hyde Fjord suggest a Cambrian age (Peel \& Higgins, 1980), though the lower levels may extend down into the late Proterozoic. The obvious correlation with the platform sequence to the south is with the Portfjeld Formation (Surlyk et al., 1980), which comprises largely dolomites (O'Connor, 1979).

Limestone conglomerates are now known from the top of the Paradisfjeld Group in southern areas of the fold belt over an east-west distance of more than $200 \mathrm{~km}$; from Borup $\emptyset$ in the west to south of Kap Ole Chiewitz in the east. They resemble the resedimented carbonate conglomerates of higher stratigraphic levels (within formations A, B \& C: Dawes 
\& Soper, 1979; Hurst \& Surlyk, 1980; Pedersen, 1980), and presumably had a similar origin as the deposits of high density debris flows derived from the carbonate platform to the south. The top of the Paradisfjeld Group in northern areas of the fold belt lacks such limestone conglomerate developments, and it is assumed that the debris flows did not extend so far north into the trough.

\section{Polkorridoren Group}

The Polkorridoren Group is widely distributed throughout the region, though the six-fold subdivision employed in eastern Johannes V. Jensen Land in 1979 (Soper et al., 1980) could not be extended into western Johannes V. Jensen Land (Map 2). Purple-coloured recessive, shale units, which proved so useful in 1979, are restricted to a few 20-50 m thick units, and these cannot be traced continuously in the highly folded mountainous terrain. Zones of relatively recessive rocks, with a higher shale proportion than other areas and thus more easily eroded, do occur; one such zone occurs at the base of the Polkorridoren Group in many areas, but it has not yet proved possible to establish a usable stratigraphy for the whole region. Thick sequences of thick bedded, often very coarse-grained, turbidites dominate the Polkorridoren Group, and are especially prominent in the high ground of Helvetia Tinde and the mountains to the west.

In northern areas between Weyprecht Sund and Nansen Land variations in stratigraphy are obscured by dense swarms of basic dykes (see below). Farther south in MacMillan $\varnothing$ and Borup $\varnothing$ a detailed lithostratigraphy can be worked out locally. The development includes shale, siltstone and thin-bedded sandstone units, but only restricted amounts of thick-bedded coarse-grained turbidites. Total thickness of the Polkorridoren sequence seems less here than in areas to the north and north-east, and seems to decrease westwards towards Nansen Land. It is possible that the sequence in these areas represents finer grained deposition at the edges or sides of the main turbidity flows or fans.

An unusual and interesting feature within the Polkorridoren Group sequence in MacMillan $\varnothing$ is the occurrence at two levels of limestone boulders. The lower level occurs within a rusty-brown shale and siltstone sequence, and three large yellow-weathering limestone boulders were noted, up to $2.5 \mathrm{~m}$ across, which are of rock types not immediately comparable to those of the Paradisfjeld Group. Sandstone boulders are more common, though rarely larger than $50 \mathrm{~cm}$ across. The higher level occurs within a distinctive sequence of pale grey quartzites, and has also been recognised in eastern Nansen Land $18 \mathrm{~km}$ to the west. The limestone boulders are more numerous here, and are generally smaller in size, though outsize blocks several metres across occur on MacMillan $\emptyset$. These deposits resemble the carbonate conglomerates at the top of the Paradisfjeld Group, and presumably also represent debris flows derived from the platform to the south. One thin but persistent cream-coloured limestone bed immediately west of Sands Fjord is the only mappable carbonate horizon of the Polkorridoren Group in northern areas.

No body fossils have yet been recorded from the Polkorridoren Group, though trace fossils are common locally; from geological arguments the Polkorridoren Group is known to be Cambrian and correlates most probably with the Buen Formation of the platform (Surlyk et al., 1980), which comprises quartzites, siltstones and shales (Jepsen, 1971; Peel, 1979; Christie \& Ineson, 1979). 


\section{Sydgletscher Group, and equivalents south of the Harder Fjord fault zone}

The Sydgletscher Group of Dawes \& Soper (1973) north of the Harder Fjord fault zone is now known to be broadly equivalent to formations A, B and C (Dawes \& Soper, 1979) south of the fault zone. This correlation is based on diagnostic fossils from the upper part (3d) of the Sydgletscher Group and lithostratigraphic comparisons (Surlyk et al., 1980; Hurst \& Surlyk, 1980). Lithostratigraphic knowledge was improved in 1980 when the Sydgletscher Group was re-examined in its type area, and the Polkorridoren Group and Paradisfjeld Group were found also on the south side of the Harder Fjord fault zone. Fig. 13 shows a general correlation. Closer comparisons are not attempted here because there are thickness and facies variations from area to area (see e.g. Pedersen, 1980), and many detailed observations by J. M. Hurst, F. Surlyk and S. A. S. Pedersen are unpublished. A revised stratigraphy in several parts by various combinations of the workers involved is in preparation.

The base of the Frigg Fjord mudstones was not previously known south of the Harder Fjord fault zone. As here they overlie the Polkorridoren Group, it is clear that they are broadly equivalent to the lowest division of the Sydgletscher Group north of the fault ( $3 a-$ Nysne Gletscher mudstones: Dawes \& Soper, 1973), a correlation which confirms the original views of Fränkl (1955) who used the term Frigg Fjord mudstones for both sequences on the basis of lithological similarity.

The Frigg Fjord mudstones are extensively exposed on southern MacMillan $\varnothing$ and Borup $\varnothing$, where they exhibit the typical green and red coloration; they form hills over $500 \mathrm{~m}$ high, and their total thickness may here reach 750-1000 m. To the east, in Amundsen Land, they are also widely exposed, and the estimates for the thickness here of at least $100 \mathrm{~m}$ (Hurst \& Surlyk, 1980) and 100-200 m (Pedersen, 1980), are, in the writers' opinion too low. Fränkl's (1955) suggestion of $400 \mathrm{~m}$ for the sequence near Sydgletscher (3a) seems to be right. However, turbidite facies can exhibit rapid variations in thickness, and it is not certain that all the purple and green mudstones depicted on Map 2 as Frigg Fjord mudstones were deposited in exactly the same time interval.

\section{Development of the North Greenland trough}

The recognition of both the Paradisfjeld Group and Polkorridoren Group south of the Harder Fjord fault zone has some implications for the evolution model for the North Greenland Lower Palaeozoic trough as proposed by Surlyk et al. (1980). The southern trough margin is considered to be controlled by major faults, and some older fault systems are considered to have become intrabasinal with time, but the implication of fig. 3 of Surlyk et al. that a precursor to the Harder Fjord fault zone was such an intrabasinal fault and influenced sedimentation is not supported by the new evidence. There are no significant differences in the development of the Paradisfjeld Group north and south of the present fault zone between Moa $\varnothing$ and Nansen Land which might indicate the existence of an intrabasinal fault in this region. The Polkorridoren Group does show some variations in thickness and facies on the two sides of the present fault zone, but these appear to reflect normal variations in the sources of supply of the sedimentary fill. 


\section{Structures}

For the purpose of this report it is convenient to divide the region mapped in 1980 into three structural zones: (1) from south of Lurgletscher to a line joining Harder Fjord, Kap Holger Danske and southern Nansen Land; (2) the islands west of Weyprecht Sund as far as eastern Nansen Land; and (3) the mountainous region east of Weyprecht Sund as far as Polkorridoren (Map 2). The $F_{1}, F_{2}, F_{3}$ fold phases ( $S_{1}, S_{2}, S_{3}$ cleavages) refer to the three phases of E-W trending coaxial folding recognised by Dawes \& Soper $(1973,1979)$ and Soper et al. (1980). The similar notation $\left(F_{1}, F_{2}\right)$ used by Pedersen $(1980)$ to describe the anomalous structures of Amundsen Land is not directly correlateable.

\section{Lurgletscher to Harder Fjord - Kap Holger Danske - southern Nansen Land}

Most of this area was studied only during helicopter reconnaissance. Folds first appear a few kilometres south of Lurgletscher in the Silurian turbidites (formation C) as large E-W trending symmetrical structures of low amplitude and gentle limb dips; as previously established (Dawes \& Soper, 1973, 1979), the southern boundary of the fold belt is gradual and not thrust. Tighter, assymetric, south-verging folds occur in the central part of Adolf Jensen Fjord, and at Kap Bopa the structures are tighter still, with inversion and associated thrusting, and affect the sedimentary pile from the Frigg Fjord mudstones through to formation $\mathrm{C}$. At Kap Holger Danske large-scale north facing folds are seen which apparently refold earlier tight folds and associated minor thrusts. To the east of Kap Holger Danske the lower part of formation A and the upper part of the Frigg Fjord mudstones are repeated many times by steep, easterly dipping, imbricate thrusts. This is the westernmost part of the Amundsen Land region, shown by Pedersen (1980) to be characterised by thrust fault tectonics and anomalous strikes.

\section{Weyprecht Sund to eastern Nansen Land}

The area is characterised throughout by northward verging tight to isoclinal major folds; they become progressively tighter from south to north. They are notably long-limbed, high-amplitude folds (fig. 14) and evidently indicate considerable shortening across the fold belt. Folding is attributed to the $F_{1}$ and $F_{2}$ fold phases (Soper et al., 1980), although it is often not possible to assign individual folds to a particular phase. Both $S_{1}$ and $S_{2}$ cleavages are developed in pelitic lithologies. South of the Harder Fjord fault zone the folds plunge gently eastwards. North of the fault zone the fold axes plunge gently eastwards on Moa $\varnothing$ and Hazen Land, are horizontal in northern MacMillan $\varnothing$ and Borup $\varnothing$, and plunge gently westwards in eastern Nansen Land (Map 2). Fold structures cannot be traced continuously in the monotonous developments of the Polkorridoren Group in the northernmost areas, where they are obscured by an intense $\mathrm{N}-\mathrm{S}$ trending dyke swarm.

In MacMillan $\varnothing$ and Borup $\varnothing$ chains of tight, major, E-W trending folds can be traced in the Paradisfjeld Group and the Polkorridoren Group (fig. 15). They plunge eastwards towards Kap Bopa and Kap Holger Danske, but evidently do not directly correlate with the different style of folding developed there. It would appear that individual fold structures have not been propagated through the thick, incompetent, Frigg Fjord mudstones. 


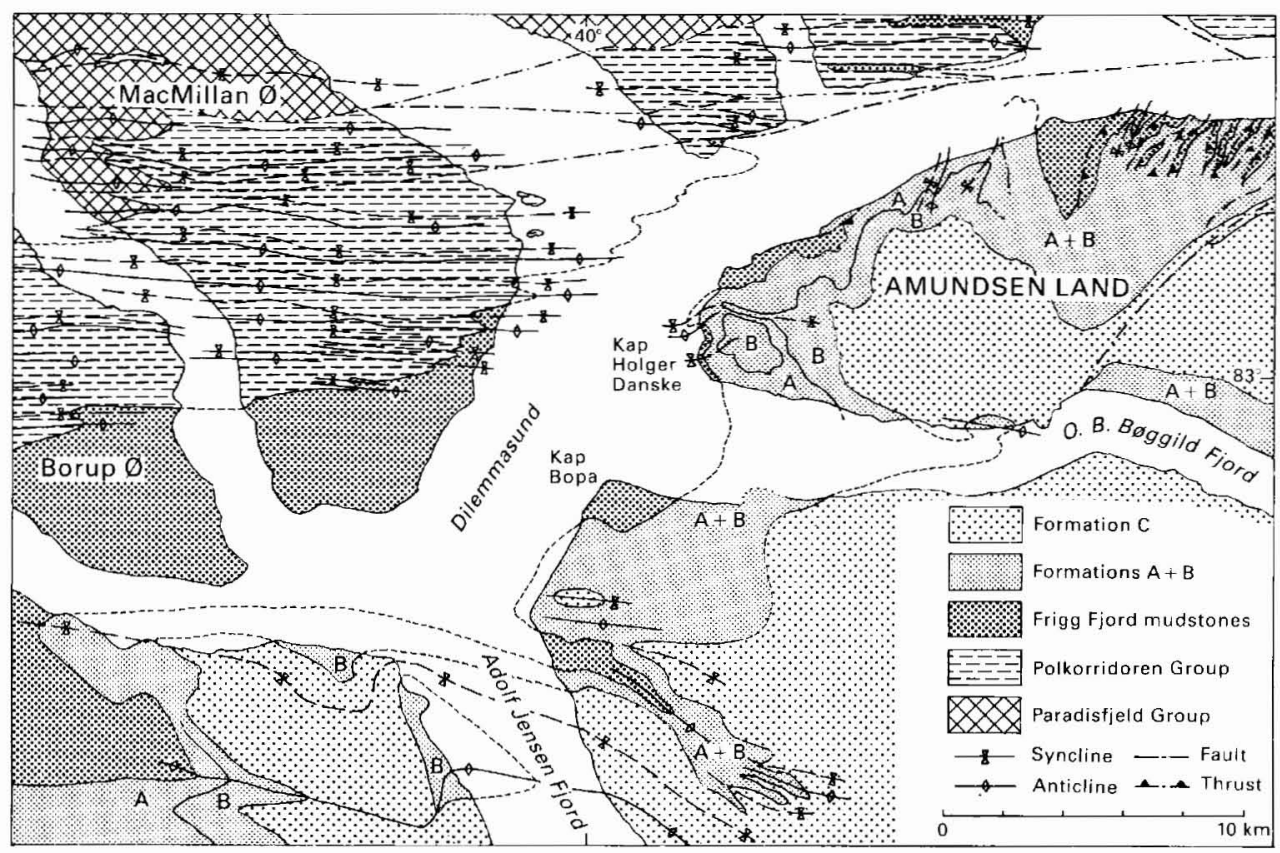

Fig. 15. Geological and structural map of part of the area mapped in 1980 (see also Map 2). Note regular development of E-W trending folds in the Polkorridoren Group and Paradisfjeld Group, stratigraphically below the Frigg Fjord mudstones. Structures in formations A, B and C, above the Frigg Fjord mudstones, include N-S trending folds, imbricate thrusts, and north and south facing E-W trending folds. Amundsen Land area modified after Pedersen (1980).

\section{Weyprecht Sund to Polkorridoren}

This area, western Johannes V. Jensen Land, is characterised by several phases of northwards verging E-W trending folds. In a broad zone north of the Harder Fjord fault zone, axial planes dip southwards at steep to moderate angles. Farther north axial plane inclinations decrease, and very large, nearly recumbent structures characterise a zone about $10 \mathrm{~km}$ wide. These folds are attributed to the $F_{1}$ and $F_{2}$ fold phases, but as elsewhere it is only in fortuitous sections that these two phases can be clearly distinguished.

$F_{3}$ structures dominate in Gertrud Rask Land in the extreme north. The complex outcrop pattern (Map 2) results from $F_{3}$ refolding of major, recumbent $F_{1}$ or $F_{2}$ anticlines, conspicuous because Paradisfjeld Group carbonates make up the $F_{1}$ or $F_{2}$ fold cores. The $S_{3}$ schistosity is first seen in the region between A. Harmsworth Gletscher and Paradisfjeld dipping steeply southwards. Northwards it becomes more flat lying and intensely developed, and is accompanied by northwards verging folds on all scales. The $F_{3}$ structures are characterised by highly variable, sometimes very steep, fold plunges.

The three main coaxial fold phases, all of which are represented by northerly overturned major fold structures, can be assigned to a mid-Palaeozoic orogeny - the Ellesmerian orogeny of the Canadian Arctic islands. Later Cretaceous - Tertiary (Eurekan) orogenic 
structures include the Kap Cannon thrust zone and Harder Fjord fault zone, both described below, and probably other minor structures; however, it has not yet proved possible to differentiate fully the structural elements developed in the two orogenies.

\section{Metamorphism}

Metamorphic grade is generally low, and increases very gradually northwards in the region. Slates are present in southern areas (Moa $\varnothing$, MacMillan Ø) although psammitic lithologies are little recrystallised. In northern Hazen Land and Johannes V. Jensen Land west of Benedict Fjord, pelites have a phyllitic fabric with greenschist facies assemblages, while psammites are still incompletely recrystallised. In Gertrud Rask Land the main prograde metamorphism reaches low amphibolite facies with sporadic occurrence of garnet, staurolite, cordierite and andalusite. There is widespread retrogression in northern areas.

The main prograde metamorphism is certainly related to the mid-Palaeozoic orogenic episode. The retrogression in northern areas seems to be associated with $F_{3}$, and is therefore also in part Palaeozoic, but some retrogression may also be attributed to the regional Tertiary overprinting of the Palaeozoic mineral assemblages which has disturbed the mineral isotopic systems (Dawes \& Soper 1971, 1979).

\section{Harder Fjord fault zone}

The Harder Fjord fault zone comprises several parallel faults which have now been traced for over $200 \mathrm{~km}$ from east of Depotbugt in the east to Nansen Land in the west (Map 2). In its eastern portion down-faulted representatives of the Wandel Sea Basin succession are preserved; these include non-marine Upper Permian (Wagner et al., in press), marine Cretaceous, and Tertiary sediments (Croxton et al., 1980). Some of these sequences were re-examined in 1980 by Håkansson et al. (this report). In 1980 greenstones were found in a discontinuous narrow zone west of Grønnemark extending almost to Drengs Bræ, and also in a small area east of Depotbugt (Map 2); the age of these greenstones, and those earlier reported from north of Midtkap (Soper et al., 1980), is unknown. North of Harder Fjord a wedge of formations A \& B is down-faulted against Polkorridoren Group both to the north and to the south; a few kilometres to the east, near Drengs Bræ a wedge of formation $\mathrm{C}$ is similarly down-faulted.

Overall movement on the fault shows substantial relative uplift of the northern block. At one point on Moa $\varnothing$, Paradisfjeld Group carbonates to the north are juxtaposed against Frigg Fjord mudstones to the south, indicating a throw approximately equivalent to the thickness of the Polkorridoren Group - perhaps 1500 to $2000 \mathrm{~m}$ if due allowance is made for the uncertainties arising from the intense folding. The fault plane of the northernmost fault is well exposed in the eastern cliffs of Hazen Land, where it dips steeply southwards at about $65^{\circ}$. No significant strike-slip displacement can be demonstrated.

Important NW-SE trending splays run off the north side of the Harder Fjord fault zone (Map 2). In 1980 one fault was traced from the north side of Nornegæst Dal to west of Benedict Fjord, and has an estimated downthrow to the south-west of about $1000 \mathrm{~m}$. A second fault with substantial downthrow also to the south-west is thought to run along Weyprecht Sund. 


\section{Kap Cannon thrust zone}

In the north of the fold belt the Tertiary Kap Cannon thrust zone brings Lower Palaeozoic metasedimentary flysch over late Cretaceous volcanic rocks of the Kap Washington Group (Dawes \& Soper, 1970; Brown \& Parsons, this report). The main thrust can be traced from Kap Cannon as far as Lockwood $\varnothing$, and the inclination of the thrust plane varies from about $40^{\circ}$ southwards at Kap Cannon to near vertical on the west side of Lockwood $\varnothing$. Two further steep thrusts or reverse faults occur to the north of the main Kap Cannon thrust, and bound wedges of Lower Palaeozoic flysch, and Carboniferous - Permian and Cretaceous sediments (Håkansson et al., this report) in addition to the volcanic rocks. There are relatively narrow zones of brecciation and mylonitisation along the thrust plane, but south of the thrust dolerite dykes cutting the folded flysch are altered into greenstones up to $1 \mathrm{~km}$ from the thrust, while intense shearing along dyke margins is found several kilometres to the south-east. North-south trending dykes on south Lockwood $\varnothing$ and in southern Kap Kane peninsula, traced northwards show a swing in trend eastwards into sub-parallelism with the thrust, but it is uncertain whether this distortion is directly associated with the thrust, or is part of the original pattern of dyke intrusion (see below).

\section{Basic dyke swarms}

Basic dykes are common in the North Greenland fold belt, and were reported from widely separated localities by earlier workers (Koch, 1923, 1925; Fränkl, 1955; Ellitsgaard-Rasmussen, 1955; Dawes \& Soper, 1970; Pedersen, 1980). The regional mapping in 1979 and 1980 has shown a distinct pattern of distribution (fig. 16). Scattered N-S trending dykes occur in the region east of Polkorridoren, but west of Polkorridoren they increase in density, and from Benedict Fjord to eastern Nansen Land form a dense swarm. In northern Hazen Land and Inge $\varnothing$ up to 20 per cent of outcrop is formed by dykes; most dykes are $3-30 \mathrm{~m}$ in width, though a number of outsized examples are up to $200 \mathrm{~m}$ wide. Some thick bodies have a sheet-like form, dipping generally eastwards at moderate angles. Scattered E-W trending dykes, apparently older than the main swarm, have been observed in Nansen Land, Luigi Amadeo $\varnothing$, Lockwood $\varnothing$ and east and south-east of Benedict Fjord. Some of the N-S dykes seem to swing in trend to join up with this E-W zone. When first seen on Lockwood $\varnothing$ and the southern Kap Kane peninsula, this change in trend was thought to be associated with retrogression and shearing attributed to the proximity to the Kap Cannon thrust, but it may be an original intrusion feature.

The main dyke swarm dies out abruptly southwards, such that few of the abundant dykes on Hanne $\varnothing$ and Inge $\varnothing$, for example, cross the sound to Borup $\varnothing$ and MacMillan $\varnothing$; they may however continue at depth. None of the $\mathrm{N}-\mathrm{S}$ dykes seem to reach the Harder Fjord fault zone, though some on Moa $\varnothing$ and north of Nornegæst Dal come very close to it. South of the fault zone a more scattered swarm of prominent WNW-ESE and E-W trending dykes is seen.

The main dyke swarm post-dates the $F_{1}, F_{2}$ and $F_{3}$ fold phases. Pedersen (1980) reported a few thin dykes in Amundsen Land intruded between his $F_{1}$ and $F_{2}$ deformation phases, but these must belong to an earlier, unrelated, intrusion event; he also reports a younger generation of E-W dykes cross-cutting all deformation structures.

The main dyke swarm predates the Kap Cannon thrust zone. Traced towards the thrust 


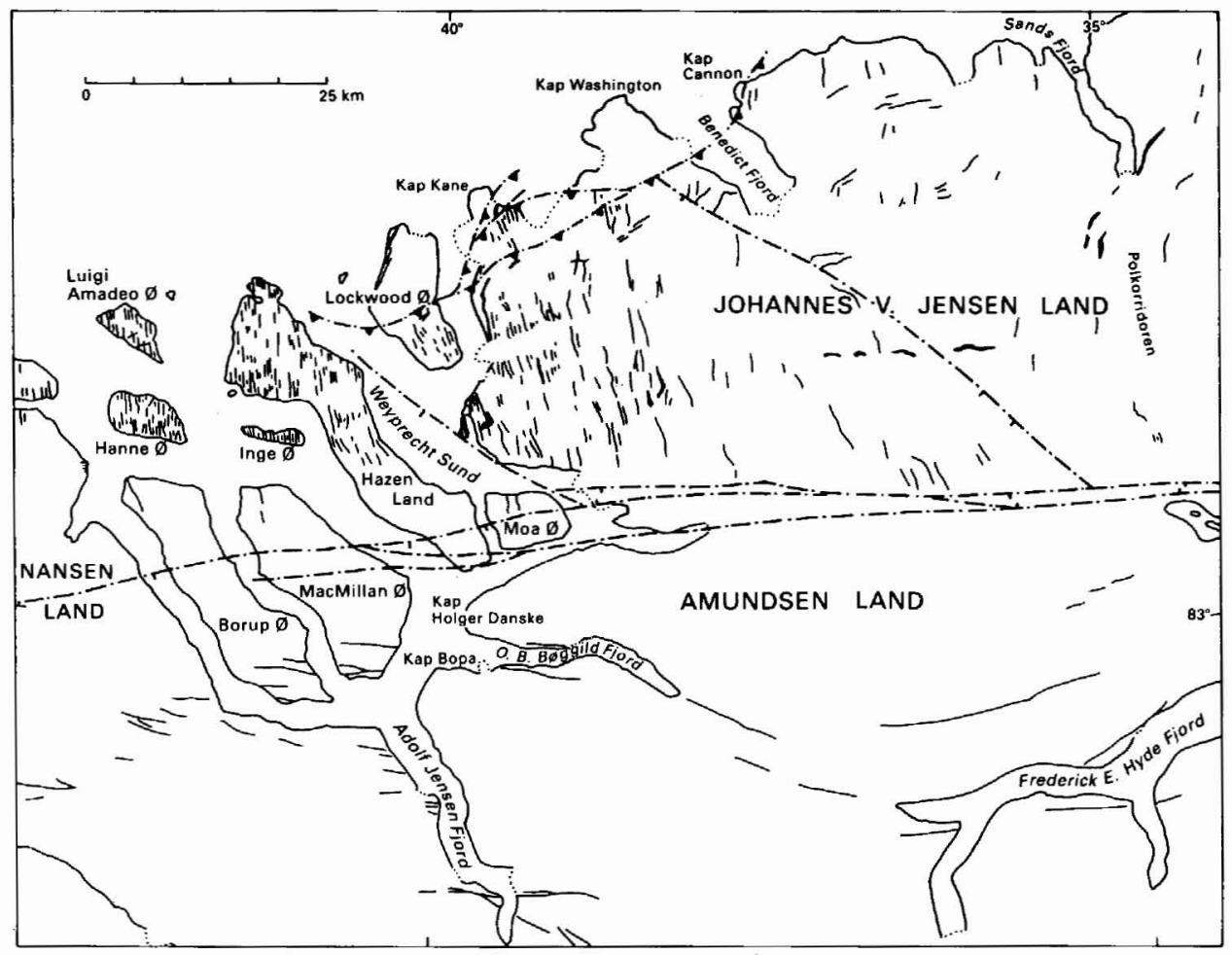

Fig. 16. Basic dyke swarms between Nansen Land and Polkorridoren. Dykes in Amundsen Land after Stig Schack Pedersen (personal communication, 1981).

the dykes become brecciated and ultimately schistose, and partly retrograded to greenschist assemblages. North of the thrust, presumably related, steeply inclined sills, presumed to be the same age as the main dyke swarm, cut the Carboniferous - Permian and Cretaceous sediments (Håkansson et al., this report), but do not cut the Kap Washington Group volcanics (Brown \& Parsons, this report). Their age is thus likely to be Cretaceous, which agrees with initial results of K-Ar age determinations (Dawes \& Soper, 1971, 1979), though a number of higher apparent ages (excess argon?) have also been obtained (P. R. Dawes, personal communication, 1981).

There is no doubt that the late Cretaceous - Tertiary events in northernmost Greenland (Harder Fjord fault zone, Kap Cannon thrust zone, Kap Washington Group, basic dyke swarms) are on-shore reflections of the development and evolution of the adjacent ocean basins. Some discussion of their significance in this context is given by Soper et al. (in press). 


\section{References}

Christie, R. L. \& Ineson, J. R. 1979; Precambrian - Silurian geology of the G. B. Schley Fjord region, eastern Peary Land, North Greenland. Rapp. Grønlands geol. Unders. 88, 63-71.

Croxton, C. A., Dawes, P. R., Soper, N. J. \& Thomsen, E. 1980: An occurrence of Tertiary shales from the Harder Fjord Fault, North Greenland fold belt. Rapp. Grønlands geol. Unders. 101, 61-64.

Dawes, P. R. \& Soper, N. J. 1970: Geological investigations in northern Peary Land. Rapp. Grønlands geol. Unders. 28, 9-15.

Dawes, P. R. \& Soper, N. J. 1971: Significance of K/Ar age determinations from northern Peary Land. Rapp. Grønlands geol. Unders. 35, 60-62.

Dawes, P. R. \& Soper, N. J. 1973: Pre-Quaternary history of North Greenland. In Pitcher, M. G. (edit.) Arctic Geology. Mem. Amer. Ass. Petrol. Geol. 19, 117-134.

Dawes, P. R., \& Soper, N. J. 1979: Structural and stratigraphic framework of the North Greenland fold belt in Johannes V. Jensen Land, Peary Land. Rapp. Grønlands geol. Unders. 93, 40 pp.

Ellitsgaard-Rasmussen, K. 1955: Features of the geology of the folding range of Peary Land, North Greenland. Meddr. Grønland 127(7), 56 pp.

Fränkl, E. 1955: Rapport über die Durchquerung von Nord Peary Land (Nordgrönland) im Sommer 1953. Meddr Grønland 103(8), $61 \mathrm{pp.}$

Hurst, J. M. \& Surlyk, F. 1980: Notes on the Lower Palaeozoic clastic sediments of Peary Land, North Greenland. Rapp. Grønlands geol. Unders. 99, 73-78.

Jepsen, H. F. 1971: The Precambrian, Eocambrian and early Palaeozoic stratigraphy of the Jørgen Brønlund Fjord area, Peary Land, North Greenland. Bull. Grønlands geol. Unders. 96 (also Meddr Grønland 192,1) 42 pp.

Koch, L. 1923: Preliminary report upon the geology of Peary Land, Arctic Greenland. Amer. J. Sci. (5),5, 189-199.

Koch, L. 1925: The geology of North Greenland. Amer. J. Sci. (5),9, 271-285.

O'Connor, B. 1979: The Portfjeld Formation (?early Cambrian) of eastern North Greenland. Rapp. Grønlands geol. Unders. 88, 23-28.

Pedersen, S. A. S. 1980: Regional geology and thrust fault tectonics in the southern part of the North Greenland fold belt, North Peary Land. Rapp. Grønlands geol. Unders. 99, 79-87.

Peel, J. S. 1979: Cambrian - Middle Ordovician stratigraphy of the Adams Gletscher region, south-west Peary Land, North Greenland. Rapp. Grønlands geol. Unders. 88, 29-39.

Peel, J. S. \& Higgins, A. K. 1980: Fossils from the Paradisfjeld Group, North Greenland fold belt. Rapp. Grønlands geol. Unders. 101, 28 only.

Soper, N. J., Higgins, A. K. \& Friderichsen, J. D. 1980: The North Greenland fold belt in eastern Johannes V. Jensen Land. Rapp. Grønlands geol. Unders. 99, 89-98.

Soper, N. J., Dawes, P. R. \& Higgins A. K. in press: Cretaceous - Tertiary magmatic and tectonic events in North Greenland and the history of adjacent ocean basins. In Dawes, P. R. \& Kerr, J. W. (edit.) Nares Strait: a central conflict in plate tectonic studies of the Arctic. Meddr Grønland, Geoscience.

Surlyk, F., Hurst, J. M. \& Bjerreskov, M. 1980: First age-diagnostic fossils from the central part of the North Greenland fold belt. Nature 286, 800-803.

Wagner, R. H., Soper, N. J. \& Higgins, A. K. in press: A late Permian flora of Pechora affinity in North Greenland. Submitted to: Rapp. Grønlands geol. Unders. 